\title{
Health Cadres in Fighting Dengue Hemorrhagic Fever
}

\author{
Nur Siyam ${ }^{1}$, Dyah Mahendrasari Sukendra ${ }^{2}$, Yunita Dyah Pustita Santik ${ }^{3}$ \\ \{nursiyam@mail.unnes.ac.id ${ }^{1}$, dyahmahendra@yahoo.com ${ }^{2}$, puspta.santik@gmail.com ${ }^{3}$ \} \\ Universitas Negeri Semarang, Semarang, Indonesia ${ }^{123}$
}

\begin{abstract}
The number of dengue fever in Semarang City has increased. Community empowerment to realize a village that is able to combat DHF. The purpose to analyze the capacity of village health cadres in the fight against DHF. This type of research is descriptive study. The study was conducted in the endemic area of Semarang City. Data collection instruments are questionnaires and checklist sheets about knowledge and practices of cadres in the fight against DHF. The subject were thirty health cadres. The results showed that the average cadre knowledge value was $84.0 \%$, the average attitude value was $80.8 \%$ and the DHF prevention and control practice was $82.5 \%$. The suggestion to increase cadre capacity to realize a village that is able to fight DHF. The community leaders and community participation needed to realize the cadre performance in order to reach the sustainability of the DHF eradication program launched by the government.
\end{abstract}

Keywords: Health cadres, DHF, Knowledge, Attitude, Practice.

\section{Introduction}

Dengue Hemorrhagic Fever (DHF) is a disease caused by dengue virus which is transmitted through the bite of the Aedes aegypti mosquito as the main vector. Nowadays, dengue fever is still one of the public health problems in Indonesia that cannot be optimally suppressed. The incidence of DHF can increase due to environmental factors, geographical conditions, behavior, and conditions of citizens' immunity [1,2].

One effort that has been made to overcome DHF is focused on eradicating the adult mosquito, Aedes aegypti, given the eradication of mosquito nests using chemicals such as larvacides can cause resistance if the dosage is incorrect [3]. Whereas eradication of mosquitoes by fogging can only kill the adults but cannot simultaneously terminate the eggs and larvae [4]

Among the provinces in Indonesia which is still a DHF endemic area is Central Java namely Semarang Regency. The DHF Incidence Rate (IR) recorded in Semarang Regency in 2016 is increased compared to the previous year. DBD IR in 2016 amounted to 98.7 per 100,000 population of 993 cases found and treated. The community still considers that fogging is the most effective way to eradicate DHF so that putting aside mosquito nest eradication (PSN) which is actually the most effective way to eradicate DHF [5]. 
The emergence of dengue cases in various DHF endemic areas in Semarang is not only caused by environmental conditions, geographical conditions and also the presence of dengue vector mosquitoes, also caused by people's behavior that is not yet aware of the importance of PSN and independent monitoring of mosquito larvae. Eradication of mosquito nests is the main point that can be done to save residents from the danger of dengue. Community empowerment is very much needed to create a Healthy Village that is free of disease vectors, especially the Aedes aegypti Mosquito.

The result of environment monitoring in Semarang, shows the practice of eradicating mosquito nests is still poor. The public is not yet aware of the importance of preventing DHF. The water reservoirs in residents' houses are not well managed. In addition, the potential of garbage that is not handled properly can lead to breeding grounds for disease vectors such as Aedes aegypti mosquitoes in used bottles, used glass, old tires, etc.

Health cadres are workers from the community who are chosen by the community and work together for the community voluntarily. Community health cadres can also mean men or women chosen by the community and trained to deal with public health problems. Health cadres have a major role in efforts to improve the ability of the community to help themselves to achieve optimal health status. A form of cadre participation is in energy and materials. Cadres also play a role in community development in the health sector through activities carried out at posyandu. Health cadres are expected to be able to provide learning experiences or create conditions for individuals, families, groups and communities [6]. Cadres should be able to open communication, provide information and conduct education to improve knowledge, attitudes and behaviors to help people recognize and overcome their own problems so that The community is aware, willing and able to practice clean and healthy life behavior through a leadership approach (Advocacy), community development (Social Support) and community empowerment [7]. Cadres must be able to increase knowledge, change attitudes and behavior of the community in monitoring DHF vectors because the community is involved in problem solving [8].

The role of the community in making the villages that safe from dengue must begin early. They must be involved and participate actively in the fight against DHF. The control and prevention of DHF must be carried out by all residents coordinated by the Village Health Cadre. Village Health Cadres in the confronting against DHF need to be trained to recognize the signs of DHF symptoms, proper PSN techniques, environmental management, measurement of larval density, how to report suspects / cases of DHF to the party appointed by the local health center. For this reason, research on "Health Cadres in Fighting Dengue Hemorragic Fever" needs to be carried out in Semarang with the aim of knowing how much the capacity of health cadres to fighting DHF, so that understanding, practices of dengue prevention by health cadres and to coordinate DHF case reporting between the community, cadres, and health workers. 


\section{Methods}

The research type is observational with quantitative descriptive approach. It was conducted in one of the endemic areas of DHF in Semarang, namely in the Village of Pakintelan, Gunungpati District, Semarang City. The research was conducted from March to May (3 months). Sampling of this research was done by total sampling technique, the number of respondents were 25 health cadres, 1 village midwife, and community leaders (community leader's wife, and Village Elders).

The research was began with coordination with the Village Chief of Pakintelan community RT 01 , then carried out socialization to the cadres to convey the purpose and objectives of conducting research. Data was collected by distributing online questionnaires that were made with Google Form and distributed through the WhatsApp group application in the concerned RT. The data taken was the data of knowledge, attitudes and practices. Knowledge data related to the causes of DHF, vector, vector life cycle, breeding grounds, and how to eradicate the vector. Attitude data is related to the cadre's attitude in creating environmental conditions that are not compatible with mosquito breeding. Practical data taken is environmental management data and practices of preventing DHF by cadres both themselves, their families and community members. Descriptive data analysis by looking at the distribution value, frequency and percentage.

\section{$3 \quad$ Results and Discussions}

Pakintelan Village is one of the dengue endemic areas which is part of the Gunungpati sub-district, Semarang City which has a high number of dengue cases. The geographical location makes Pakintelan a suitable place to become the habitat of the Aedes aegypti mosquito. In addition, the community has high mobility close to densely populated urban areas.

Research activities began on March 2020 with the coordination of the research team. The research began by coordinating and licensing with the head of Pakintelan Village. After being allowed to conduct research, the team coordinated with RT01 community leader and his wife. The research team conducted observations and interviews with community leader's wife and the elder community leaders. All coordination is carried out with an online system because when the research was conducted the Covid-19 Pandemic occurred. After determining the schedule that was adjusted to the leisure time with the cadres, the research team distributed links / pages that must be filled by cadres and conducted interviews with the RT and several Cadres related to the obstacles and efforts made in the fight against DHF.

From the results of interviews and observations with community leaders and village cadres can be concluded that the prevention and control of DHF have been going well. Coordination of the eradication of mosquito nests from the Puskesmas to the regional office is carried out in each RT assisted by health cadres. Waste management and the environment have been done by carrying out environmental cleaning work once a month which is conducted in the first week of every month. Household waste has been managed by the sub-district cleaning staff with a fee of Rp. 25,000 each family. Residents' houses that have large bathtubs that are difficult to drain will al- 
ways be monitored and reminded to be drained once a week. Many residents have started raising fish to be able to eat the existing mosquito larvae. Some residents have manipulated the bathroom by using the tub from a bucket. But there are still some who do not care about the surrounding environment, which is still throwing garbage, cans or pots / washbasins into the garden so that it becomes a puddle.

The research involved 25 health cadres. All cadres were female. Cadre characteristics are presented in Table 1.

Table 1. Characteristic of Health Cadre

\begin{tabular}{|c|c|c|c|c|}
\hline No & Characteristics & Category & frequency & $\%$ \\
\hline \multirow[t]{3}{*}{1} & Age & $31-40$ & 20 & 80 \\
\hline & & $41-50$ & 4 & 16 \\
\hline & & $51-60$ & 1 & 4 \\
\hline \multirow[t]{4}{*}{2} & Job & Teacher & 5 & 20 \\
\hline & & Worker & 5 & 20 \\
\hline & & $\begin{array}{l}\text { Others (private sectors, pri- } \\
\text { vate business) }\end{array}$ & 6 & 24 \\
\hline & & Housewife & 9 & 36 \\
\hline \multirow[t]{4}{*}{3} & Education & Bachelor & 3 & 12 \\
\hline & & Senior High & 14 & 56 \\
\hline & & Junior High & 7 & 28 \\
\hline & & Elementary & 1 & 4 \\
\hline \multirow[t]{2}{*}{4} & Coaching/training of DHF & Ever & 10 & 40 \\
\hline & & Never & 15 & 60 \\
\hline
\end{tabular}

Source: Primary Data, 2020

Table 1 shows that most of village health cadres were aged 31-40 years (80\%), there was one cadre who aged more than 50 years of age (4\%). Health cadres mostly earn a living as private workers and entrepreneurs, namely $24 \%$ and housewives $(36 \%)$. The most recent education of cadres was high school graduated $(56 \%)$. In addition, most of them had received counseling / training about DHF (60\%).

The results showed that values of knowledge, attitudes and behavioral practices of DHF prevention are as follows; an average knowledge score of $84.0 \%$, an average attitude score of $80.8 \%$ and an average score of prevention and control of DHF is $82.5 \%$.

Health cadres need guidelines to carry out their role in preventing and controlling DHF in the regions where they are responsible. A guidebook will help and provide instructions so that the activities carried out are on target and in accordance with the objectives. It can contain definitions of dengue fever, signs and symptoms, morphology of Aedes aegypti mosquitoes, life cycle of mosquitoes, habits / behavior of Aedes aegypti mosquitoes, mosquito breeding sites, ways of preventing dengue and steps to carry out eradication of dengue mosquito nests, control of extraordinary events. DHF, list of important behaviors to prevent it and how to calculate mosquito larvae density. Guidance is given to cadres as a guide in fighting DHF.

Increasing the knowledge of village health cadres about dengue fever can be done through the provision of material and training by puskesmas surveillance officers that are carried out gradually and continuously. The hope is that with increasing cadre knowledge, cadres' attitudes and practices will also improve in fighting DHF. A 
good attitude will encourage cadres to always be motivated in carrying out their duties voluntarily. Direct practice that can be done is to identify risky places as mosquito breeding sites. Identification of risky places to be breeding grounds for mosquitoes is carried out by cadres through the form provided.

The physical environment greatly affects the presence of vector of dengue disease [9]. The presence of A. aegypti mosquitoes is determined by the specific topography of the place, climate (rainfall, temperature, humidity, and wind speed) and the level of life of the people. In areas with a lot of man-made water reservoirs (drums, jars, bathtubs), many are found A [10]. In addition, community behavior factors are very important in controlling environmental conditions around them. It is cadres who are the spearhead of technical implementers in preventing DHF that is closest to the community.

The capacity of village health cadres in the fight against DHF will increase over time with the support of community leaders, stake holders, health workers and the community itself. Health cadres are the people chosen to be able to help solve health problems in the community. Health cadres need to be selected with heterogeneous socio-demographic criteria to be able to become role models in communities with different socio-demographic strands.

Cadre practices in preventing DHF in their own homes will become the foundation in the practice of preventing DHF in the community. Communication, education and information related to dengue prevention are very important given to health cadres so that they are able to invite the community to participate in the eradication of mosquito nests routinely once a week, in unison by all residents and continuously. Health cadres also need to be equipped with knowledge materials about dengue including signs and symptoms, mosquitoes / vectors, appropriate PSN, ways of reporting / coordination if there are cases / suspects and ways of handling and preventing DHF, so that they are able to provide information about behaviors that are at risk of increasing the incidence DBD [11]. The tasks of cadres in the community need to be written clearly in their work program. So that they can immediately take action to improve DHF prevention practices in preventing DHF cases routinely in the community.

A motivating cadre who is always enthusiastic will create a community that has resources and capability readiness and a willingness to prevent and overcome DHF and emergency problems related to DHF. Communities can create healthy lives, and care and respond to health problems in their areas supported by all walks of life. Cadre is very helpful in the success of preventing DHF areas that are prone to DHF and DHF endemic areas [12].

The success of controlling DHF is inseparable from the role of government, stake holders, community leaders, including religious leaders and also related sectors, strengthened by community participation in the Eradication of Mosquito Nest (PSN) [13] Implementing 3M Plus, namely: 1) Drain and brush walls of water reservoirs such as bathtubs once a week, 2) Closing water storage, 3) Recycling items that can hold rain water can be sustainable if there is a high commitment from the health program holder and from the community [14]. These activities are complemented by Plus activities, such as replacing flower vase water, dumping water in water reservoirs in dispensers, sprinkling larvae powder in places that are difficult to clean, maintaining mosquito larvae, and using repellents. DHF control really requires contributions from 
housewives, both cadres and non-cadres, because the implementation is closely related to housework that implements a clean and healthy culture in their daily lives [15].

Cadres are expected to be able to provide learning experiences or create conditions for individuals, families, groups and communities [7]. Cadres are able to open communication, provide information and conduct education to improve knowledge, attitudes and behaviors to help people recognize and overcome their own problems so that the community is aware, willing and able to practice clean and healthy life behavior through the approach of the leader (Advocacy), community development (Social Support) and community empowerment [7]. The community is involved in solving the problems they face [8].

Coordination between cadres and village health workers and support of community leaders in preventing DHF will increase the speed and accuracy in handling the environment to prevent DHF in the case of DHF cases, and create a clean and healthy environment [16].

\section{Conclusion}

Knowledge, attitudes and practices of health cadres become the foundation in the success to fight DHF. The prevention and control of DHF by health cadres must be supported by stakeholders, community leaders and the community itself so that the role of the cadre is carried on optimally. It is recommended that any DHF disease prevention and control program always involve community participation as a cadre, get support from community leaders local health workers and stakeholders.

\section{Acknowledgments}

We would like to acknowledge the Institute of Research and Community Service (LP2M) and the Faculty of Sport Science, Semarang State University, which provided research funding.

\section{References}

[1]. K. Alagarasu, T. Honap, Mulay, Bachal, Shah, and Cecilia, "Association of vitamin D receptor gene polymorphisms with clinical outcomes of dengue virus infection," Hum. Immunol., vol. 73, pp. 1194-1199, 2012.

[2]. N. Siyam, S. A. Wilopo, and M. Hakimi, "Asupan Vitamin D Rendah dan Keparahan Demam Berdarah Dengue pada Anak Usia 1-14 Tahun,” Kesmas UI J. Kesehat. Masy. Nas., vol. 9(1), 2014.

[3]. A. Cornel, J. Holeman, C. Nieman, Y. Lee, C. Smith, and M. Amorino, "Surveillance, insecticide resistance and control of an invasive Aedes aegypti (Diptera: Culicidae) population in California," F1000Research, vol. 5, p. 194, 2016, doi: Epub 2016/05/10.

[4]. P. Packierisamy, C. Ng, M. Dahlui, J. Inbaraj, V. Balan, and Y. Halasa, "Cost of Dengue Vector Control Activities in Malaysia.,” Am J Trop Med Hyg, vol. 93, no. 5, pp. 10201027, 2015, doi: Epub 2015/09/30. 
[5]. N. Siyam, "Integrated and Comprehensive Action to Reduce and Control Dengue Hemorrhagic Fever: A Survey in Pekalongan City, Central Java,” Trop. Med. J., vol. 03, no. 1, pp. 85-93, 2013.

[6]. H. an den Berg, A. von Hildebrand, V. Ragunathan, and P. Das, "Reducing vector-borne disease by empowering farmers in integrated vector management," Bull. World Health Organ., vol. 85, no. 7, pp. 561-6, 2007, doi: Epub 2007/09/05.

[7]. A. Diliyanti, "PHBS di Lingkungan Pondok Pesantren," [Online]. Available: http://adenovitadiliyanti-kemprut.blogspot.com/p/phbs-di-pesantren.html.

[8]. E. Nalwanga and J. Ssempebwa, "Knowledge and practices of in-home pesticide use: a community survey in Uganda," J. Environ. Public Health, pp. 1-7, 2011, doi: Epub 2011/07/22.

[9]. N. Arunachalam, S. Tana, F. Espino, P. Kittayapong, W. Abeyewickreme, and K. Wai, "Eco-bio-social determinants of dengue vector breeding: a multicountry study in urban and periurban Asia," Bull Word Heal. Organ, vol. 88, pp. 173-84, 2010.

[10]. I. Mulyawan, Pola Sebaran dan Faktor Risiko Kejadian DBD di Kota Kendari Tahun 2010. Yogyakarta: Universitas Gajah Mada, 2011.

[11]. N. Siyam and W. Cahyati, "Implementation of School Based Vector Control (SBVC) for the Prevention and Control of Disease Vectors in Schools," Media Kesehat. Masy. Indones., vol. 14, no. 1, 2018.

[12]. H. Nawalah, M. Qomaruddin, and R. Hargono, "Desa Siaga: Upaya Pemberdayaan Masyarakat di Bidang Kesehatan Melalui Peran Bidan di Desa," Indones. J. Public Heal., vol. 8, no. 3, pp. 91-98, 2012.

[13]. N. Siyam, "The Facilitation of KD-RS and W2 DHF Report to Improve DHF Surveillance Report," KEMAS J., vol. 8, no. 2, 2013.

[14]. C. Mutero, D. Schlodder, N. Kabatereine, and R. Kramer, "Integrated vector management for malaria control in Uganda: knowledge, perceptions and policy development," Malar J., vol. 11, p. 21, 2012, doi: Epub 2012/01/17.

[15]. J. Sommerfeld and A. Kroeger, "Innovative community-based vector control interventions for improved dengue and Chagas disease prevention in Latin America: introduction to the special issue,” Trans R Soc Trop Med Hyg, vol. 109, no. 2, pp. 85-88, 2015, doi: Epub 2015/01/22.

[16]. Rina, "Gambaran Persepsi Masyarakat Terhadap Peran dan Motivasi Bidang untuk Menurunkan Angka Kesakitan DBD Di Desa Siaga Margo Mulyo Tahun 2017,” J. Midwifery, vol. 6, no. 1, pp. 26-32., 2018. 